○特集 低炭素化社会へ貢献する分離膜

\title{
水素分離シリカ膜を搭載した水素製造膜反応器
}

\author{
赤松憲樹*・中尾真一 \\ 工学院大学 工学部 環境エネルギー化学科 \\ 于 192-0015 東京都八王子市中野町 2665-1
}

\section{Membrane Reactors for Hydrogen Production with Hydrogen-selective Silica Membranes}

\author{
Kazuki Akamatsu* and Shin-ichi Nakao \\ Department of Environmental and Energy Chemistry, Faculty of Engineering, Kogakuin University \\ 2665-1, Nakano-machi, Hachioji-shi, Tokyo 192-0015, Japan
}

A membrane reactor is a system that integrates "reaction" with catalysts and "separation" with membranes. As reaction and separation occur simultaneously in a membrane reactor, the endothermic equilibrium reactions, such as hydrogen production reactions, can be shifted forward beyond the thermodynamic equilibrium by extracting one of the generated components, hydrogen in this case, from the reaction system using a membrane. Actually, there are many reports and ideas concerning the development of membrane reactors for hydrogen production from dehydrogenating organic chemical hydrides such as cyclohexane or methylcyclohexane, decomposing hydrogen sulfide, or steam reforming of hydrocarbons. However, most membrane reactors have been developed using palladium or its alloyed membranes due to their unique separation mechanism and excellent hydrogen-selective performance. Recently, there are some reports on the hydrogen-selective silica membranes that match palladium-based membranes in hydrogen permeance and in hydrogen selectivity. In addition, some fundamental studies on the membrane reactors using the hydrogen-selective silica membranes with such excellent hydrogen-selective performances have also been reported. In this review, recent progresses on the membrane reactors for hydrogen production equipped with hydrogen-selective membranes, especially amorphous silica membranes, are described.

Key words : membrane reactors / silica membranes / equilibrium shift / hydrogen / high purity / organic chemical hydrides / hydrogen sulfide / hydrocarbons / steam reforming / chemical vapor deposition

\section{1.はじめに}

膜反応器（メンブレンリアクター）とは，反応と 分離を同時に行い, 効率的に目的物を得る反応器シ ステムのことである ${ }^{1 \sim 4)}$. 下排水処理技術として近

* Corresponding Author

Tel: 042-628-4584

Fax: 042-628-4542

E-mail: akamatsu@cc.kogakuin.ac.jp
年注目を集めている膜分離活性污泥法（Membrane Bioreactor, MBR) や，発酵槽に微生物を担持した 膜を浸漬し発酵と同時に生成物と原料を分離するバ イオリアクターなども膜反応器の 1 種と言えるが, 本 総説では気相系の平衡反応，とくに水素製造反応系 に膜を組み込み, 平衡シフトを実現し高効率な水素 製造を主目的とした膜反応器に焦点を絞る。水素製 造のための膜反応器では, Fig. 1に示すように, 水素 のみを選択的に透過させる分離膜を反応器内に搭載 することで, 水素製造反応と同時に水素の分離・精 


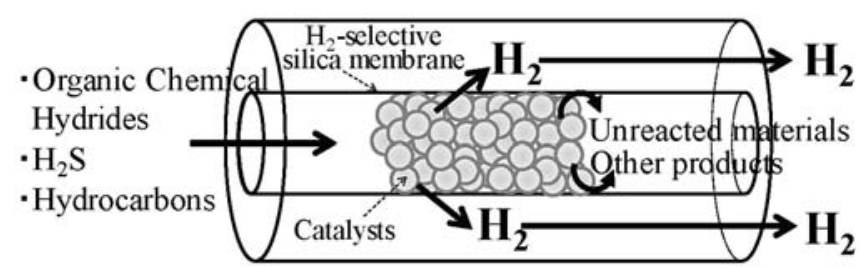

Fig. 1 Conceptual illustration of membrane reactors for hydrogen production.

製を行い，これと同時にル・シャトリエの法則に説 明されるように，水素が選択的に引き抜かれること より平衡反応を生成物側にシフトさせ，転化率を向 上させることが可能となる. すなわち水素製造反応 において, 熱力学的制約を超える高転化率を実現し, 反応温度を低下させることができるだけでなく, 後 段に新たな分離プロセスを配することなく高純度の 水素を製造することができる，現在までに，様々な 水素製造反応系に対する膜反応器の研究開発報告例 があるが, 本稿では有機ハイドライド脱水素反応系 への適用を中心に解説し，その後，他の反応系への 適用例についても簡単に紹介する.

\section{2. 水素製造膜反応器に搭載するための水素 分離膜}

膜反応器の性能を決めるキーコンポーネントの1つ は，言うまでもなく「膜」である．水素分離膜とし ては，ポリイミドをべースとするポリマー系 ${ }^{5 \sim 7)}$, パラジウムをベースとする金属系 ${ }^{8 \sim 10)}$, シリカなど のセラミック系 ${ }^{11 \sim 14)}$ の3 種類が考えられる. しかし, ポリマー系の水素分離膜は高温では使用できない. 水素貯蔵材料からの水素放出温度を $150{ }^{\circ} \mathrm{C}$ 以下に低減 し車載などを実現したいという要請があるが，仮に 膜反応器を用いてこの程度まで反応温度を低下させ ることができれば，ポリマー系の水素分離膜の使用 可能性も多少見えてくる. しかし，現時点ではその ような水素製造反応系は提案されて抢らず，難しい. パラジウム系金属膜は,「溶解拡散機構」という特異 な水素分離メカニズムを特長とし, 水素透過率・水 素分離係数のいずれもきわめて高く, 性能が良いこ とから多くの研究がなされてきた. 現在も水素分離 膜の研究開発の主流はパラジウム系金属膜であり, 水素製造膜反応器開発例もパラジウムをべースとし た金属系の水素分離膜を搭載したものが多い. 東京 ガスの千住水素ステーションにおける膜反応器を用 いた高純度水素製造の実証試験など成果も着実にあ がっている．しかしパラジウムは埋蔵量の極めて少 ない貴金属である．パラジウムの国別供給シェアは
ロシアと南アフリカで8割以上となっているが, この 供給も安定的なものでなく価格変動が大きい. また 総需要の 6 割以上が先進国での自動車触媒と電子・電 気部門に集中しており，2050年には現有埋蔵量を使 い切るとの予想もある. 水素社会構築の必要性が叫 ばれている昨今, 水素分離膜の需要はますます大き くなってくることが容易に予想されるが，パラジウ 厶系金属膜でこれにすべて応えるのは難しいと言 えよう。また有機ハイドライド脱水素反応系など, $200 \sim 300^{\circ} \mathrm{C}$ 程度の低温領域での膜反応器使用を考え る場合, パラジウムには水素脆化という問題も生じ る.これに対しセラミック系多孔膜は, 細孔より小 さい分子のみを透過させるという「分子篩機構」に より水素分離能を発現する. 室温から $600{ }^{\circ} \mathrm{C}$ 程度の高 温領域まで安定した分離性能を示し, 水素脆化とい う問題も起こり得ない. またコスト面でも金属系水 素分離膜より有利であると考えられている. しかし, セラミック系の水素分離多孔膜を搭載した水素製造 のための膜反応器の開発例はそれほど多くないのが 現状である.

分子篩機構により水素分離を行うセラミック系多 孔膜は, シリカをべースマテリアルとしたものが多 い. 膜反応器に搭載する場合も水素分離膜に求めら れる性能は, 高い水素透過率と高い水素選択性の両 立である. 一般に水素透過率が大きいほど水素引き 抜き効果が大きくはたらくため平衡シフトによる高 転化率の達成に有利である. 加えて, 単位膜面積あ たりの水素製造速度を向上させることができる．換 言すると, 装置の小型化が実現可能となる. また水 素選択性が大きいほど高純度の水素を得ることがで きる.このためには細孔径が, 水素の大きさより大 きく, 水素以外の分離対象気体種の大きさよりもわ ずかに小さい，という膜細孔構造が望まれる。 シク ロヘキサン一ベンゼン系の有機ハイドライド脱水素 反応系への適用を例にすると, 水素, シクロへキサ ン, ベンゼンの kinetic diameterはそれぞれ $0.289 \mathrm{~nm}$, $0.60 \mathrm{~nm}, 0.59 \mathrm{~nm}$ であるから ${ }^{15)}$, 細孔径としては $0.55 \mathrm{~nm}$ 程度の膜が最も適していると言える. 水素分 離シリカ膜についても, 研究開発が始まった当初は, 水素と窒素を効率的に分離可能な, $0.3 \mathrm{~nm}$ 程度の細 孔を有する膜の報告例が多かったが, 近年では草 壁・諸岡らのグループ16, 17), 赤松・中尾らのグルー プ18)による, シリカプレカーサーの化学構造に着目 した細孔径拡大制御技術も報告されており，それぞ れの水素製造反応系に相応しい水素分離シリカ膜の 開発も可能となりつつあり, 膜反応器への搭載も検 討されつつある. 


\section{3. 有機ハイドライド脱水素反応系への適用}

\section{1 反応系の意義}

有機ハイドライドとは水素を共有結合により取り こんだ芳香族化合物のことであり, 脱水素反応によ り水素供給が，水素添加反応により水素貯蔵が可能 となる，水素キャリアとして最も期待されているも のの1つである. 他の水素キャリアと比較して, 高い 水素貯蔵密度が実現でき，また一般に常温常圧で液 体であるため（ナフタレンを除く），取扱いが容易で 既存のインフラが利用できる，といった利点が挙げ られる.ガソリンの取扱いに対する安全性について は日本に限らず世界中でコンセンサスが取れている と言ってよいが, 有機ハイドライドはガソリンとほ ぼ同等に取扱うことができる，有機ハイドライドの 代表的な系は以下の 3 つであり, いずれも平衡吸熱反 応である。

$$
\begin{array}{r}
\mathrm{C}_{6} \mathrm{H}_{12} \text { (シクロヘキサン) } \leftrightarrow \mathrm{C}_{6} \mathrm{H}_{6} \text { (ベンゼン) }+3 \mathrm{H}_{2} \\
\mathrm{C}_{6} \mathrm{H}_{11}-\mathrm{CH}_{3} \text { (メチルシクロヘキサン) } \\
\leftrightarrow \mathrm{C}_{6} \mathrm{H}_{5}-\mathrm{CH}_{3} \text { (トルエン) }+3 \mathrm{H}_{2} \\
\mathrm{C}_{10} \mathrm{H}_{18} \text { (デカリン) } \\
\leftrightarrow \mathrm{C}_{10} \mathrm{H}_{8} \text { (ナフタレン) }+5 \mathrm{H}_{2}
\end{array}
$$

中でもメチルシクロヘキサン一トルエン系は, 平衡 転化率が高いことや寒冷地でも凝固しない程度の凝 固点を有することなどメリットも多く，最も代表的 な有機ハイドライド系であると言える.

水素キャリアとしての有機ハイドライドは, 偏在 する自然エネルギーを利用する水素社会の構築のた めに不可欠と考えられている。自然エネルギー利用 型水素社会においては以下のようなシステムが可能 性の1つとして提案されている. 水力や風力, 太陽光 発電といった偏在する自然エネルギーを利用して水 の電気分解を行い, 水素に変換する. これを水添反 応により有機ハイドライドとして貯蔵する．水添反 応は発熱反応であるため熱供給は不要であり，水添 反応技術は既にプラントスケールで確立されている. よってこの点に技術的課題はない. 有機ハイドライ ドの車載・船載による輸送は，有機ハイドライドの 一部から水素を取り出し，これを輸送エネルギーと することができる．原油を海外から輸送するのと全 く同様の考え方である. 残りの有機ハイドライドは, ユースポイントでの脱水素反応により水素を取り出 す．脱水素反応は製造水素のみを分離可能な膜反応 器を用いて効率的に行う. 脱水素反応後の反応物は
再び水添反応を実施し，有機ハイドライドとして利 用する．これは，来るべき水素社会に向けた有望な システムであると言える.

\section{2 有機ハイドライド脱水素膜反応器に用いられ る触媒}

膜反応器に用いるための触媒といっても特別な触 媒が用いられるわけではなく, 従来の触媒研究で性 能が良いとされる触媒が用いられることが一般的で ある. 有機ハイドライド脱水素反応用としては, $\mathrm{Pt}^{19}$ $\left.\left.\sim 21), \mathrm{Ni}^{22)}, \mathrm{Pd}^{23} 25\right), \mathrm{MoO}_{3}{ }^{26}\right), \mathrm{Ru}^{27}$ ), さらにはバイ メタリック $28 \sim 30)$ な触媒の検討例が報告されている が，概して $\mathrm{Pt} / \mathrm{Al}_{2} \mathrm{O}_{3}$ 触媒が性能が良いとされ，多く 用いられている。ただし最も代表的なメチルシクロ ヘキサン一トルエン系の脱水素反応においては, 次 のような脱メチル反応が副反応として起こることが 問題とされている.

$$
\mathrm{C}_{6} \mathrm{H}_{11}-\mathrm{CH}_{3}+\mathrm{H}_{2} \rightarrow \mathrm{C}_{6} \mathrm{H}_{12}+\mathrm{CH}_{4}
$$

さらにこの副反応により生成するメタンは分子サイ ズが有機ハイドライドに対して小さいため, 水素と ともに膜を透過するとこの副反応が促進されること も懸念されている. この副反応は $\mathrm{Al}_{2} \mathrm{O}_{3}$ 担体がルイス 酸として働くことが原因と指摘されている. そのた め, 岡田らは $\mathrm{Al}_{2} \mathrm{O}_{3}$ の酸点をカリウムでマスキングす ることでこの副反応が抑制できると報告している ${ }^{31}$.

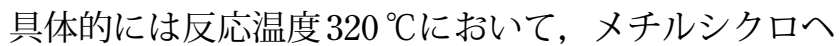
キサン転化率 $95 \%$ 以上，トルエンの選択性 $99.9 \%$ 以上 という性能を，6,000 時間以上達成できたと報告して いる. また $\mathrm{Pt} / \mathrm{Al}_{2} \mathrm{O}_{3}$ 触媒に比べて, $\mathrm{PtRe} / \mathrm{Al}_{2} \mathrm{O}_{3}$ 触媒 はベンゼンの生成量を抑制することができるという 報告もある ${ }^{32,33)}$.

\section{3 膜反応器の開発例}

有機ハイドライド脱水素膜反応器は, 水素分離膜 としてパラジウム膜 34 38) やゼオライト膜 ${ }^{39)}$, 無機 多孔膜 $40 \sim 41$ ) を搭載したものが報告されている. パ ラジウム膜を搭載した膜反応器は, パラジウム膜に 起因する高い水素透過率と高い水素選択性により良 好な平衡シフトを実現したとの報告が多い. 無機多 孔膜を搭載した膜反応器としては， $y$ アルミナ膜を 搭載したものなどが報告されているが，ゼオライト 膜を搭載した膜反応器を含めて, 水素透過率は高い ため平衡シフトは実現されているものの, 膜が高い 水素選択性を有していないケースが多い。すなわち 高い水素透過率と高い水素選択性を兼敉備えた水素 分離無機膜を搭載した有機ハイドライド脱水素膜反 


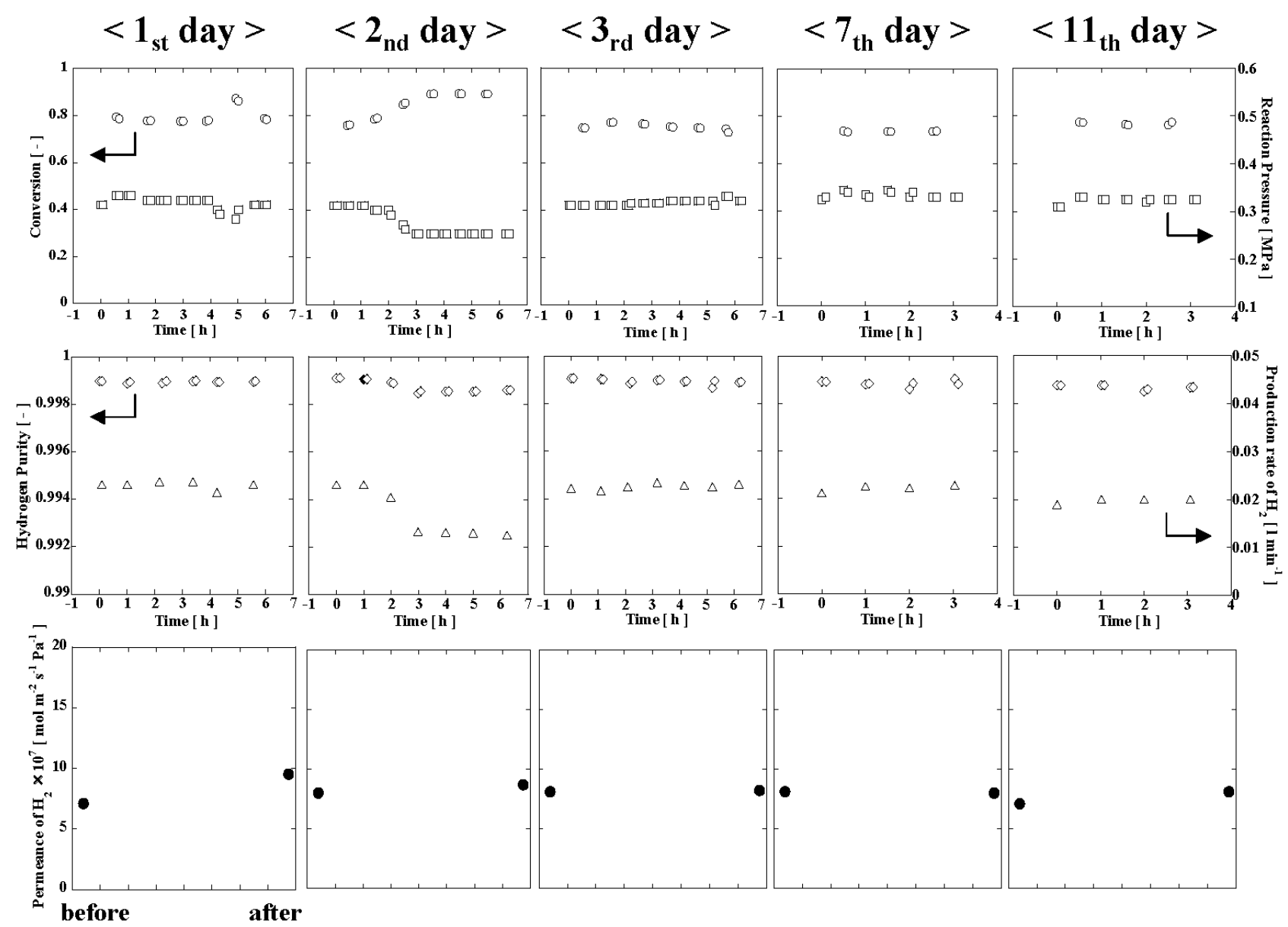

Fig. 2 Production of hydrogen from cyclohexane using the membrane reactor with DMDPS-derived membrane. (from 43))

応器の開発例はほとんどない.

赤松・中尾らは，テトラメトキシシラン (TMOS), TMOSのメトキシ基の 2 つをフェニル基に 置換したジメトキシジフェニルシラン（DMDPS）と 酸素のCVD法によりシリカ膜を製膜し，これを有機 ハイドライド脱水素膜反応器へ搭載する水素分離膜 とした. TMOS膜とDMDPS膜ではDMDPS膜の方 が高い水素透過率と高い水素選択性を示し， $300{ }^{\circ} \mathrm{C}$ に おいて水素透過率が $10^{-6} \mathrm{~mol} \mathrm{~m}^{-2} \mathrm{~s}^{-1} \mathrm{~Pa}^{-1}$ を上回り， $10^{4}$ 程度の水素 $/ \mathrm{SF}_{6}$ 選択率を示す。触媒として $\mathrm{Pt} / \mathrm{Al}_{2} \mathrm{O}_{3}$ 触媒粒子を管状膜内部に充填した膜反応器 により評価を行った. 483〜 563 Kの温度領域, ある いは $0.1 \sim 0.8 \mathrm{MPa}$ の圧力領域で，十分な滞留時間の 下でシクロヘキサン脱水素反応試験を行った結果, いずれの条件下でも，水素分離膜の替わりに気体非 透過のSUSチューブを用いた反応器では平衡転化率 と同程度の転化率を示した。一方で，TMOS膜を用 いた膜反応器は，いずれの条件下でも平衡を上回る 反応転化率を示し, DMDPS膜を用いた膜反応器はこ れよりさらに高い転化率を示した ${ }^{42)}$ 。これらの平衡 シフトの挙動は, 同時に開発された膜反応器シミュ レーションにより予測される挙動とよく一致した。
これは製造水素の選択的引き抜き効果によるもので あり，水素の透過率が高い DMDPS 膜の方がその効 果が大きい.

DMDPS膜を搭載したシクロヘキサン脱水素反応器 を, 原料を膜反応器へ供給するためのキャリアガス や，透過側水素分圧を下げることで効率的に水素引 き抜きを図るためのスイープガスを使用することな く, 原料シクロヘキサンを加圧して反応器内へ供給 し, 分圧差を利用して透過側に常圧の高純度水素を 得る実験を行った結果を Fig. 2 に示す ${ }^{43}$. 膜面積は $9.4 \times 10^{-4} \mathrm{~m}^{2}$, シクロヘキサン供給量は $5 \sim 10 \times 10^{-6}$ mol s${ }^{-1}$ である。実験は DSS（Daily-StartupShutdown）運転として行われ, 反応温度は $583 \mathrm{~K}$ で あった． 1 日目， 2 日目， 3 日目は 6 時間運転を， 4 日 後の 7 日目, さらに 4 日後の 11 日目には 3 時間運転を 行った. GCによって求められた1日目の反応転化率 と水素純度はそれぞれ $80 \%$ と $99.9 \%$ であり，6時間の 膜反応器運転の間, 安定した值を示した。これらの 值は 2 日目以降の運転でもほぼ同様の值を, 安定して 示した。これはDSS 運転期間において, DMDPS膜 と触媒が安定して機能していたことを表している. 11 日目の製造ガスの光イオン化 MS 測定の結果を 


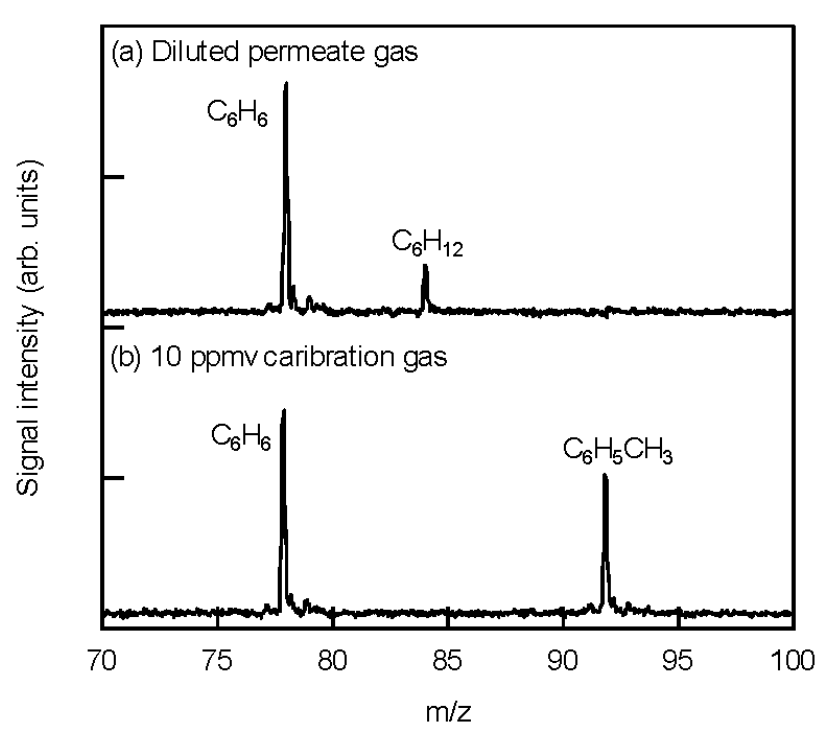

Fig. 3 (a) Mass spectrum of the permeate gas diluted to $1 \%$ in nitrogen, (b) mass spectrum of $10 \mathrm{ppmv}$ VOCs calibration gas. (from 43))

Fig. 3 に示す ${ }^{43)} . m / z 78,84$ のシグナルが検出され, これはベンゼンとシクロへキサンに対応する。すな わち製造ガス中には水素以外に，反応物であるべン ゼンと未反応シクロへキサンのみが含まれることが 明らかとなった。換言すると，シクロへキサジエン やシクロヘキサンなどの不純物は含まれていないこ とが分かった。これは完全な脱水素反応が膜反応器 で起こっているか, あるいはわずかにこれらの不純 物が含まれるものの透過側で検出されない程度に微 量であることを意味し，いずれにしても望ましい結 果である。ささらに定量評価を行い，ベンゼンとシク ロへキサンの濃度が $0.118 \%, 0.043 \%$ であったことが 報告されている。これらの結果も GCによる測定結果 と矛盾しない.

原料をメチルシクロヘキサンに変更して, 同様に, キャリアガスおよびスイープガスを使用することな く膜反応器の DSS運転を行い，常圧水素を得る検討 も行われている ${ }^{44)}$. 膜反応器は同様にDMDPS膜を 搭載したもので，反応温度は $533 \mathrm{~K}$ とし，1日あたり 6 時間の運転を 3 日続けたものである. メチルシクロ ヘキサン脱水素反応の場合も同様に，GCによって求 められた 1 日目の反応転化率と水素純度はそれぞれ $80 \%$ と $99.95 \%$ であり，6時間の膜反応器運転の間，安 定した值を示していた. シミュレーションにより予 測した反応転化率と水素純度はそれぞれ $86 \%$ と 99.98 \%であり，よい一致を示している．これらの值は 2 日 目以降の運転でもほぼ同様の值を安定して示して いた.

実は，このようなキャリアガスやスイープガスを
使用しない膜反応器の運転報告例は非常に少ない. 水素分離シリカ膜を搭載した水素製造膜反応器に限 定すると， キャリアガスやスイープガスを用いるこ となく安定して運転した報告例は，これが初めてで ある.キャリアガスやスイープガスを用いて運転す ると, 製造水素からこれらのガスを分離する後処理 が必要となる. 膜反応器では反応と同時に分離を行 うことで, 後処理を行うことなく高純度の目的物を 得ることができることが最大の特長の1つであるはず であり，この特長に矛盾する。このような運転条件 での安定した高純度水素製造が可能となったことの 意義は非常に大きい. 実際に, シクロへキサン脱水 素膜反応器のキャリアガス, スイープガスを使用し ない運転において, 製造ガスを市販の然料電池へ直 接供給する実験を行うと, 燃料電池は非常に安定し た発電性能を示したと報告されている ${ }^{43)}$. これは得 られた製造ガス中の水素純度が $99.9 \%$ 程度と非常に高 純度であったことと, 膜反応器からの水素製造速度 が非常に安定していたことに起因すると考えられる.

\section{4 膜反応器シミュレーションと解析}

膜反応器性能を予測するシミュレーションも多く 報告されているが, 分圧差をドライビングフォース とした各種ガス成分の膜透過速度と脱水素反応速度 のカップリングにより記述された1次元シミュレーシ ヨンモデルが多い。これはマスバランスにのみ着目 した非常にシンプルで化学工学的なモデルであるが, 適用性は広く実験結果を説明するには十分である。 このようなモデルは等温系を仮定したものが多いが, 一方で, 有機ハイドライド脱水素反応のような大き な吸熱エンタルピー変化を伴う反応系を対象とする 膜反応器において, この等温系という仮定が妥当で ない可能性は否定できない. また1次元シミュレーシ ヨンでは複雑な流路形状・反応器形状を記述するこ とはできない。すなわち，実験結果を簡便に説明す るシミュレーションは行われていたが, シミュレー ションから装置設計へ展開するという理想的な研究 開発例はほとんど行われていないという問題があっ た. 伊藤らはCFD (Computational Fluid Dynamics, 数值流体力学) の手法をべースとし, 熱移動と物質 移動を考慮した多管式膜反応器の3 次元シミュレーシ ヨンを行った ${ }^{45)}$. これにより複雑な反応器形状を有 する多管式膜反応器における有機ハイドライド脱水 素反応性能を良好に予測できることが可能となった。 さらに, 反応エンタルピー分の熱供給方法の改善や 膜管径の拡大, といった膜反応器性能向上のための フィードバックを与えることに成功している. 非常 に汎用性に富んでいると言え, 更なる研究開発の進 


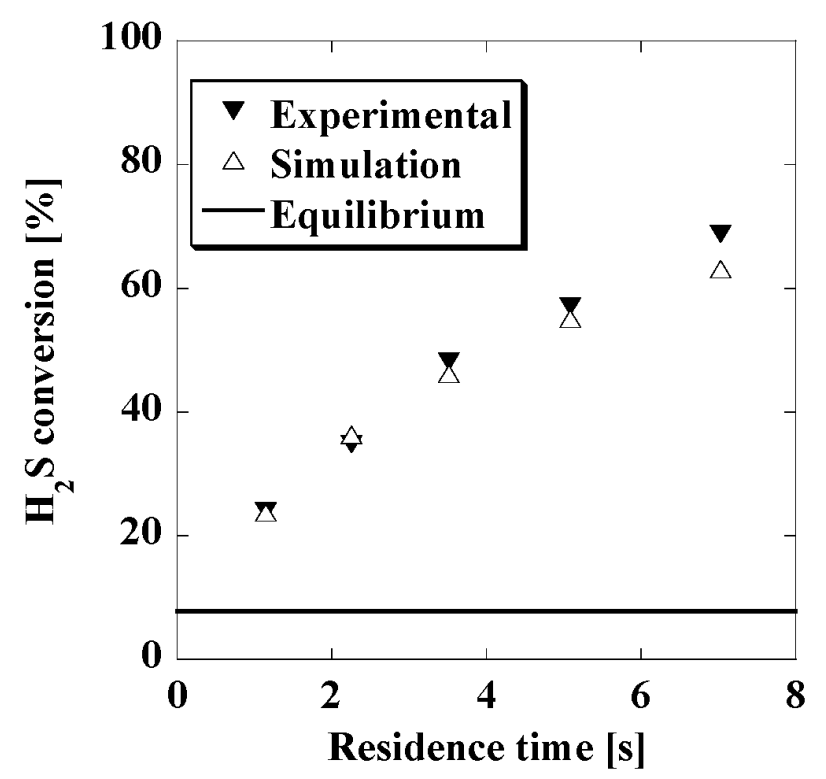

Fig. 4 Conversion of hydrogen sulfide as a function of the residence time in our membrane reactor at $873 \mathrm{~K}$. (from 49))

展が期待されている.

\section{4. その他の水素製造反応系への適用}

\section{1 硫化水素分解反応}

硫化水素は石油工業での精製工程，鉄鋼業の精錬 工程あるいは天然ガスの随伴ガスとして副生する. 硫化水素は通常クラウス法と呼ばれる方法で処理さ れており，硫黄は回収されるが，水素は水となるた め回収できない.ここで硫化水素を水素として回収 することを考えると, 硫化水素の分解が必要となる. 硫化水素の分解反応は下記の式で表される.

$$
\mathrm{H}_{2} \mathrm{~S} \leftrightarrow \mathrm{H}_{2}+1 / \mathrm{n} \mathrm{S}_{\mathrm{n}} \quad(\mathrm{n}=1 \sim 8)
$$

しかし硫化水素分解反応は吸熱平衡反応であり, そ の平衡定数も極めて小さく, 熱力学的には $20 \%$ 以上 の転化率を得るには $1200 \mathrm{~K}$ 以上の高温が必要となる. この分解反応に水素を選択的に透過する膜を搭載し た膜反応器を適用すれば，低温で高い転化率が得ら れ, 反応温度を低下させることができる. 膜反応器 を用いた硫化水素分解に関しては 30 年ほど前から提

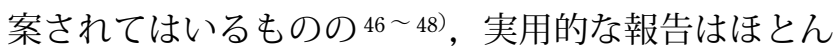
どなされていない. 特に, 高い水素透過性と高い水 素分離性を兼ね備えた無機多孔膜を搭載した硫化水 素分解膜反応器の開発例は皆無であった. 硫化水素 の kinetic diameter は窒素と同程度であるため, 0.3 $\mathrm{nm}$ 程度の細孔径を有する無機多孔膜の使用が望まし

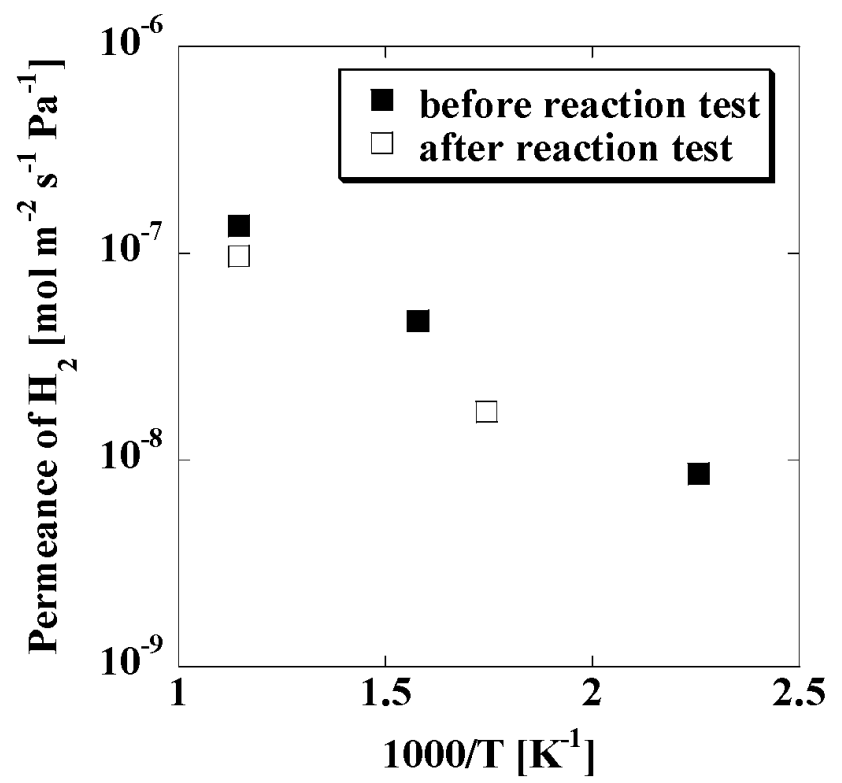

Fig. 5 Arrhenius plots for hydrogen permeation through the TMOS-derived membrane before and after the decomposition reaction test. (from 49))

いと考えられていた。

赤松・中尾らは管状のTMOS膜の内側に市販触媒 を詰めて膜反応器を作製し, 窒素ガスで $1 \%$ に希釈し た硫化水素の分解反応実験を行っている. この希釈 した硫化水素ガスを 0.45 から $2.8 \mathrm{cc} / \mathrm{min}$ で供給する ことで, 硫化水素の滞留時間を変化させた. 反応温

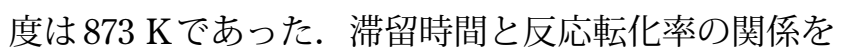
Fig. 4 に示す ${ }^{49)}$. 膜反応器に搭載したTMOS膜の製 膜直後の気体透過性能は, $873 \mathrm{~K}$ において水素は $1.4 \times 10^{-7} \mathrm{~mol} \mathrm{~m}^{-2} \mathrm{~s}^{-1} \mathrm{~Pa}^{-1}$, 窒素は $1.3 \times 10^{-11} \mathrm{~mol} \mathrm{~m}^{-2}$ $\mathrm{s}^{-1} \mathrm{~Pa}^{-1}$ であった. 本条件での平衡転化率は $7.8 \%$ と計 算されるが, 膜反応器を用いると転化率はこれを大 きく上回った。また滞留時間が長いほど高転化率を 示し， 7 秒という短い滞留時間でも転化率は $69 \%$ と, 大きく平衡転化率を上回る結果を得た. またシミュ レーションで予測した転化率は, 実験で得られた転 化率とよい一致を示した.これは水素分離シリカ膜 の安定した水素引き抜き効果と, 触媒の安定した性 能発現によるものと考えられる. また膜反応器実験 前後の膜の水素透過率を Fig. 5 に示す ${ }^{49}$ ). $873 \mathrm{~K}$ にお ける水素透過率は $1.4 \times 10^{-7} \mathrm{~mol} \mathrm{~m}^{-2} \mathrm{~s}^{-1} \mathrm{~Pa}^{-1}$ から $1.0 \times 10^{-7} \mathrm{~mol} \mathrm{~m}^{-2} \mathrm{~s}^{-1} \mathrm{~Pa}^{-1}$ となり, 水素透過性能が若 干低下したと言える．ただし膜の大きな破壊などは 認められなかった. すなわち硫化水素分解反応とい う過酷な条件下でも, 大幅な水素透過率の低下は起 こらず，比較的安定した性能を示したと言える。こ れは水素分離シリカ膜を搭載した膜反応器開発の $1 つ$ の成功例であると言える. 


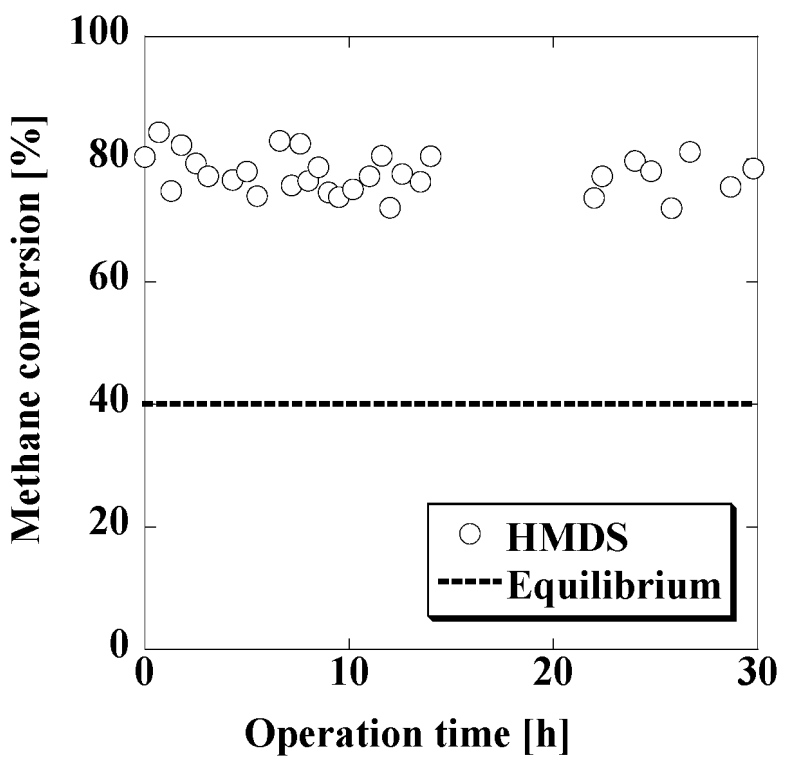

Fig. 6 Continuous production of $\mathrm{H}_{2}$ in the membrane reactor with the HMDS-derived silica membrane and $\mathrm{Ni}$ catalyst. The $\mathrm{S} / \mathrm{C}$ ratio was 2.5 , the feedrate of methane was $1.0 \times 10^{-6} \mathrm{~mol} \mathrm{~s}^{-1}$ and the reaction temperature was $773 \mathrm{~K}$. (from 52))

\section{2 メタン水蒸気改質反応}

工業的な水素製造法として, メタン水蒸気改質が 挙げられる.この反応式を以下に示す。

$$
\mathrm{CH}_{4}+\mathrm{H}_{2} \mathrm{O} \leftrightarrow \mathrm{CO}+3 \mathrm{H}_{2}
$$

これは平衡吸熱反応であり，80\%を超えるような高い 転化率を実現するためには $1100 \mathrm{~K}$ 以上の高温が必要 となる。.また副生成物の一酸化炭素は燃料電池触媒 を被毒するため，一酸化炭素に対しては何らかの処 理が必要となる。一般に以下に示すシフト反応が同 時に行われる.

$$
\mathrm{CO}+\mathrm{H}_{2} \mathrm{O} \leftrightarrow \mathrm{CO}_{2}+\mathrm{H}_{2}
$$

この反応系においても反応温度を低下させたいとい う要求が大きく, その意味からも, 水素分離膜を搭 載した膜反応器の利用による平衡シフトの実現と反 応温度低下は魅力的である。メタン水蒸気改質用膜 反応器に用いる膜は, 水素のみを透過し, 一酸化炭 素（kinetic diameter : $0.376 \mathrm{~nm}$ ）や二酸化炭素 (kinetic diameter : $0.33 \mathrm{~nm}$ ), 未反応メタン (kinetic diameter : $0.38 \mathrm{~nm}$ ）といった分子を透過しない膜が 必要となる.すなわちメタンの水蒸気改質反応にお いても硫化水素分解反応の場合と同様に, 細孔径が $0.3 \mathrm{~nm}$ 付近にある膜であれば水素のみを選択的に引 き抜くことができる．加えて高温水蒸気に対する耐
性が膜には求められる。一般的にシリカは水に弱く， シリカ膜も水蒸気雾囲気に曝されると分離性能が急 激に低下することが知られている。 シミュレーショ ンにより, メタンの水蒸気改質に水素分離膜を搭載 した膜反応器を適用すれば, 反応温度を $800 \mathrm{~K}$ 程度ま で低下させることができることは明らかになってい たが, 課題は耐水蒸気性を有するシリカ膜の開発で あった．実は前述のTMOS膜も耐水蒸気性を有して いた. $873 \mathrm{~K} て ゙$ 製膜したTMOS膜に対して, Steam/ $\mathrm{N}_{2}=3$ のガスを供給し, $773 \mathrm{~K}$ での膜性能を評価した ところ, 初期に各ガス種の透過率は若干低下するも のの, 80 時間以上安定した水素分離性能を示すこと が既に明らかとなっていた ${ }^{50)}$. ただし水素透過率は 3 $\sim 5 \times 10^{-8} \mathrm{~mol} \mathrm{~m}^{-2} \mathrm{~s}^{-1} \mathrm{~Pa}^{-1}$ とかなり小さい值で安定 するため, より高い水素透過率で安定となる耐水蒸 気性シリカ膜が求められていた。 これに対し吉野ら は，へキサメチルジシロキサン（HMDS）と酸素の 対向拡散 CVD 法で作製した膜は, 同様の水蒸気雾囲 気下で非常に安定した水素／窒素分離性能を示し, 安定化する水素透過率も $10^{-7} \mathrm{~mol} \mathrm{~m}^{-2} \mathrm{~s}^{-1} \mathrm{~Pa}^{-1}$ を上回 る值であることを報告している51).

赤松・中尾らは，管状の気体非透過のSUSチュー ブ, TMOS膜, または HMDS膜の内側に $\mathrm{Rh} / \mathrm{Al}_{2} \mathrm{O}_{3}$ 触 媒, または $\mathrm{Ni} / \mathrm{Ce}_{0.15} \mathrm{Zr}_{0.85} \mathrm{O}_{2}$ 触媒を詰めて膜反応器 を作製した. 所定比のメタンと水蒸気をフィードと して供給し，透過側を減圧することで反応を行った。 またTMOS膜, HMDS膜いずれを用いる場合も，事 前に水蒸気処理を施すことで膜性能を安定化させて から膜反応器の運転を実施した. S/C比を 3 として, メタン流量, および反応器内圧力が, 反応転化率に 与える影響を検討したところ, TMOS膜を用いた膜 反応器は平衡を上回る反応転化率を示し, HMDS膜 を用いた膜反応器はこれよりさらに高い転化率を示 した ${ }^{52)}$.これは製造水素の選択的引き抜き効果によ るものであり, 水素の透過率が高い膜の方がその効 果が大きく高転化率を示していることも妥当である と言える.さらに $\mathrm{S} / \mathrm{C}$ 比を 3 から 2.5 に変更して, $\mathrm{HMDS}$ 膜内部に $\mathrm{Ni} / \mathrm{Ce}_{0.15} \mathrm{Zr}_{0.85} \mathrm{O}_{2}$ 触媒を詰めた膜反 応器の連続運転を行った. 結果を Fig. 6に示す 52). 反 応温度は $773 \mathrm{~K}$, メタン流量は $1 \times 10^{-6} \mathrm{~mol} \mathrm{~s}^{-1}$ という 条件下での運転であり, 同条件での平衡転化率は $40 \%$ と計算されるが，膜反応器を利用することで $80 \%$ 程 度の高い転化率を，30 時間安定して示すことを明ら かにした。これは, この 30 時間の連続運転の間, HMDS膜と Ni触媒が安定に機能していたことを表わ しており,これも1つの水素分離シリカ膜を搭載した 膜反応器開発の成功例であると言える. 


\section{5. おわりに}

本稿で紹介したように，水素分離シリカ膜を搭載 した膜反応器の適用可能性は古くから提案されてお り，基礎的な研究開発は着実に進行している。一方 で，「膜の大面積化はどうするか? 」，「単位体積あた りの膜面積を大きくしつつ熱供給阻害を受けない反 応器形状はどのようなものか? 間使用できるのか?」といった，実用展開に対する 課題にもそろそろ真剣に取り組む時期にきているよ うに思われる。同時に，こういった膜反応器は燃料 電池での利用が想定されており, 燃料電池の研究開 発の進展にも期待したい.

\section{文献}

1) Tsuru T, Yamaguchi $\mathrm{K}$, Yoshioka T, Asaeda $\mathrm{M}: A I C h E ~ J$., 50, 2794-2805 (2004)

2) 伊藤直次 : Membrane, 30, 38-45 (2005)

3) Battersby S, Teixeira PW, Beltramini J, Duke MC, Rudolph V, Costa JCD : Catal. Today, 116, 12- 17 (2006)

4) Prabhu AK, Liu A, Lovell LG, Oyama ST : J. Membr. Sci., 177, 83-95 (2000)

5) Kita H, Inada T, Tanaka K, Okamoto K : J. Membr. Sci., 87, 139-147 (1994)

6) Garcia MG, Marchese J, Ochoa NA : Int. J. Hydro. Ener., 35, 8983-8992 (2010)

7) Li Y, Chung TS : Int. J. Hydro. Ener., 35, 10560-10568 (2010)

8) Garcia-Garcia FR, Ma YH, Rodriguez-Ramos I, GuerreroRuiz A : Catal. Commun., 9, 482-486 (2008)

9) Mardilovich PP, She Y, Ma YH, Rei MH : AIChE J., 44, 310-322 (1998)

10) Gade SK, Keeling MK, Davidson AP, Hatlevik O, Way JD : Int. J. Hydro. Ener., 34, 6484-6491 (2009)

11) de Lange RSA, Keizer K, Burggraaf AJ : J. Membr. Sci., 104, 81-100 (1995)

12) Tsapatsis M, Gavalas GR: AIChE J., 38 847-856 (1992)

13) Akamatsu $K$, Nakane M, Sugawara $T$, Nakao $S$ : AIChE J., 58, 2197-2200 (2009)

14) Nomura M, Ono K, Gopalakrishnan $S$, Sugawara $T$, Nakao S : J. Membr. Sci., 251, 151-158 (2005)

15) Funke HH, Argo AM, Falconer JL, Noble RD : Ind. Eng. Chem. Res., 36, 137-143 (1997)

16) Sea BK, Watanabe M, Kusakabe K, Morooka S, Kim SS : Gas. Sep. Purif., 10, 187-195 (1996)

17) Sea BK, Kusakabe K, Morooka S : J. Membr. Sci., 130, 4152 (1997)

18) Ohta $Y$, Akamatsu K, Sugawara $T$, Nakao A, Miyoshi A, Nakao S :J. Membr. Sci., 315, 93-99 (2008)

19) Sinfelt JH :J. Molecular Catal. A, 163, 123-128 (2000)
20) Cui T, Fang J, Zheng A, Jones F, Reppond A : Sensors Actuators B, 71, 228-231 (2000)

21) Tien PD, Satoh M, Miura M, Nomura M : Fuel Processing Technol., 89, 415-418 (2008)

22) Biniwale RB, Kariya N, Ichikawa M : Catal. Lett., 105, 8387 (2005)

23) Tien PD, Morisaka H, Satoh T, Miura M, Nomura M, Matsui H, Yamaguchi C : Ener. Fuel, 17, 658-660 (2003)

24) Tien PD, Satoh T, Miura M, Nomura M : Ener. Fuel, 19, 731-735 (2005)

25) Tien PD, Satoh T, Miura M, Nomura M : Ener. Fuel, 19, 2110-2113 (2005)

26) Belatel H, Kandari HA, Khorafi FA, Katrib A, Garin F : Appl. Catal A, 275, 141-147 (2004)

27) Kyomasu A, Okuhara T, Misono M : Chem. Lett., 19, 1643-1644 (1990)

28) Moraweck B, Frety R, Pecchi G, Morales M, Reyes P : Catal. Lett., 43, 85-89 (1997)

29) Ali LI, Ali AGA, Fotouh SMA, Gheit AKA : Appl. Catal A, 177, 99-110 (1999)

30) Miguel S, Castro A, Scelza O, Fierro JLG, Soria J : Catal. Lett., 36, 201-206 (1996)

31) Okada Y, Sasaki E, Watanabe E, Hyodo S, Nishijima H : Int. J. Hydro. Ener., 31, 1348-1356 (2006)

32) Coughlin RW, Kawakami K, Hasan A : J.Catal., 88, 150$162(1984)$

33) Doolittle WJ, Skoularikis ND, Coughlin RW : J.Catal., 107, 490-502 (1987)

34) Yamamoto S, Hanaoka T, Hamakawa S, Sato K, Mizukami F : Catal. Today, 118, 2-6 (2006)

35) Gora A, Tanaka DAP, Mizukami F, Suzuki TM : Chem. Lett., 35, 1372-1373 (2006)

36) Trianto A, Kokugan T : J. Chem. Eng. Japan, 34, 13321340 (2001)

37) Itoh $\mathrm{N}$, Tamura $\mathrm{E}$, Hara $\mathrm{S}$, Takahashi $\mathrm{T}$, Shono $\mathrm{A}$, Satoh K, Namba T: Catal. Today, 82 119-125 (2003)

38) Itoh N, Xu WC, Haraya K : J. Membr. Sci., 66, 149-155 (1992)

39) Jeong BH, Sotowa K, Kusakabe K : J. Membr. Sci., 224, 151-158 (2003)

40) Okubo T, Haruta K, Kusakabe K, Morooka S, Anzai H, Akiyama S : Ind. Eng. Chem. Res., 30, 614-616 (1991)

41) Ferreira-Aparicio P, Rodoriguez-Ramos I, Guerrero-Ruiz A :J. Catal., 212, 182-192 (2002)

42) Akamatsu K, Ohta Y, Sugawara T, Hattori T, Nakao S : Ind. Eng. Chem. Res., 47, 9842-9847 (2008)

43) Akamatsu K, Ohta Y, Sugawara T, Kanno N, Tonokura K, Hattori T, Nakao S : J. Membr. Sci., 330, 1-4 (2009)

44) Oda K, Akamatsu K, Sugawara T, Kikuchi R, Segawa A, Nakao S : Ind. Eng. Chem. Res., 49, 11287-11293 (2010)

45) Mimura K, Yoshida N, Sato T, Itoh N : J. Jpn. Petrol. Inst., 53, 283-291 (2010)

46) Kameyama T, Dokiya M, Fujishige M, Yokokawa H, 
Fukuda K: Ind. Eng. Chem. Fundam., 20, 97-99 (1981)

47) Gavalas GR, Megiris CE, Nam SW : Chem. Eng. Sci., 44, 1829-1835 (1989)

48) Zaman J, Chakma A : Int. J. Hydrogen Energy, 20, 21- 28 (1995)

49) Akamatsu K, Nakane M, Sugawara T, Hattori T, Nakao S :J. Membr. Sci., 325, 16-19 (2008)

50) Nomura M, Aida H, Gopalakrishnan S, Sugawara T, Nakao S, Yamazaki S, Inada T, Iwamoto Y : Desalination, 193, 1-7 (2006)

51) 吉野 泰, 安藤泰典, 田口久富, 伊藤直次 : 化学工学 論文集，34, 242-248 (2008)

52) Akamatsu K, Murakami T, Sugawara T, Kikuchi R, Nakao S : AIChE J., in press. DOI : 10.1002/aic.12404

(Received 11 March 2011;

Accepted 20 March 2011)

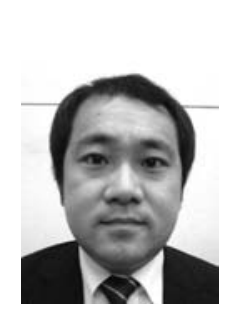

\begin{tabular}{|c|c|}
\hline 著者略歴 & \\
\hline 赤松 憲樹 & （あかまつかずき） \\
\hline 2002 年 3 月 & 東京大学工学部化学 \\
\hline & システム工学科卒業 \\
\hline 2007 年 3 月 & 東京大学大学院工学 \\
\hline & 系研究科化学システ \\
\hline & 厶工学専攻博士課程 \\
\hline & 修了＼cjkstart博士（工学） \\
\hline 2007 年 4 月 & 東京大学大学院工学 \\
\hline & 系研究科 助教 \\
\hline 2010 年 4 月 & 工学院大学工学部 \\
\hline & 助教 \\
\hline
\end{tabular}

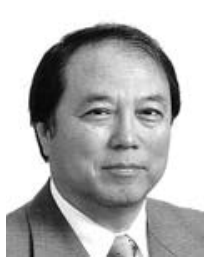

$\begin{array}{ll}\text { 中尾 真一 } & \text { (なかお しhいち) } \\ 1981 \text { 年 } 3 \text { 月 } & \text { 東京大学大学院工学 } \\ & \text { 系研究科博士課程修 } \\ & \text { 了 工学博士 } \\ 1981 \text { 年 } 12 \text { 月 } & \text { 東京大学生産技術研 } \\ & \text { 究所 助手 } \\ 1982 \text { 年 } 9 \text { 月〜 } & 1984 \text { 年 } 3 \text { 月 Twente } \\ & \text { 工科大学 (オランダ) } \\ & \text { 博士研究員 東京大 } \\ & \text { 学工学部講師 助教 } \\ & \text { 授を経て } \\ \text { 1995年 } 7 \text { 月 } & \text { 東京大学大学院工学 } \\ & \text { 系研究科 教授 } \\ \text { 2009年 } 4 \text { 工 } & \text { 工学院大学工学部 } \\ & \text { 教授 } \\ \text { 現在に至る } & \end{array}$

